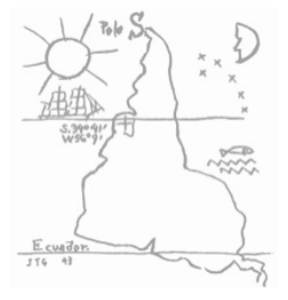

ALTERNAUTAS

Héctor Alimonda

\title{
The Coloniality of Nature: An Approach to Latin American Political Ecology
}

Alternautas is a peer reviewed academic journal that publishes content related to Latin American Critical Development Thinking.

It intends to serve as a platform for testing, circulating, and debating new ideas and reflections on these topics, expanding beyond the geographical, cultural and linguistic boundaries of Latin America - Abya Yala. We hope to contribute to connecting ideas, and to provide a space for intellectual exchange and discussion for a nascent academic community of scholars, devoted to counter-balancing mainstream understandings of development.

How to cite:

Alimonda, H. (2019), The Coloniality of Nature: An Approach to Latin American Political Ecology, Alternautas, 6(1), 102-142. URL :

http://www.alternautas.net/blog/2019/6/10/the-coloniality-of-nature-anapproach-to-latin-american-political-ecology

Editor : Alternautas

http://www.alternautas.net

London, UK.

ISSN - 2057-4924 


\section{The Coloniality of Nature: An Approach to Latin American Political Ecology $\mathbf{y}^{2}$}

Here, I propose to focus on the topic of political ecology in Latin America. It seems to me the best way to do this is to ask what it is that specifically constitutes that which, for better or worse, has come to be called "Latin America". I want to do this by recovering the analytical perspective that has been called the Modernity/Coloniality Research Program-a contemporary space of collective dialogue both in and about Latin America. The conclusion that I have drawn from this is that the catastrophic trauma of conquest and integration into a subordinate, colonial position in the international system, as the hidden and necessary other side to modernity, is the mark of origin of Latin America. Note that I am not saying that this mark of origin fatally determines absolutely all our history.

In saying this, I make clear that I consider that History has a relevant role in the interpretation of societies. Therefore, it should not be surprising that, in my opinion, Latin American political ecology must form a relationship of dialogue and feedback with another area of reflection that has recently been developing in the regionenvironmental history. ${ }^{3}$ After presenting these points, I will attempt to end this

\footnotetext{
'Translated by Alexander D'Aloia

2 This entry is a translation of the essay 'La colonalidad de la naturaleza: una aproximación a la ecología política latinoaméricana', from the collection of essays organised by Alimonda 'La naturaleza colonizada: ecología política y minería an América Latina'

This article was originally published in http://www.alternautas.net/blog/2019/6/10/thecoloniality-of-nature-an-approach-to-latin-american-political-ecology on June 10th, 2019.

3 Apart from participating in the foundation of the Latin American and Caribbean Society of Environmental History in 2004, CLACSO's Work Group of Political Ecology always included an aspect of environmental history in its meetings and publications.
} 
reflection with references to the different proposals of political ecology in Latin America.

To begin, I wish to highlight the persistent coloniality that affects the Latin American nature (as in 'environment'). It appears, as much a bio-physical reality (its flora, fauna, human inhabitants, the biodiversity of its ecosystem) as its territorial configuration (the sociocultural dynamics that significantly articulates these ecosystems and landscapes), before global hegemonic thought and before dominant elites of the region as a subaltern space, which can be exploited, levelled, and reconfigured according to the necessities of the prevailing regimes of accumulation. Over the course of five centuries entire ecosystems were levelled by the introduction of monocultures for export. Fauna, flora and humans were all victims of biological invasions of European competitors or diseases. Today it is the turn of hyper-opencut mining, of soy monocultures and agrofuels with chemical inputs that raze entire environments (including humans), of great hydroelectric projects, or of new communication channels in the Amazon, such as the infrastructure of new export cycles. Even the "ecologically correct" political orientations of the imperial centres entail environmentally catastrophic options for our region: the transfer of polluting industries, projected nuclear waste dumps, mega-monoculture of agrofuels, etc. A long history of unequal, combined development and a global rupture of the societynature metabolism increasingly penalises the Latin American nature and the people that make their lives in it (O'Connor, 2001). ${ }^{4}$

\section{The Modernity/Coloniality Perspective}

The Modernity/Coloniality (M/C) Research Program, so called by the Colombian anthropologist Arturo Escobar (2005b), consists of a recent perspective from Latin

\footnotetext{
4 Victor Toledo (2008), presenting a typology of human appropriation of nature, offers a definition of "colonised nature': "appropriated ecosystems have lost such abilities" (of selfmanagement and self-reproduction) "and require a fortriori external energy (human, animal, or fossil) to maintain itself. In the absence of human action, these 'artificial ecosystems' either regenerate and recover through mechanisms of ecological restoration, or deviate in bizarre forms, atypical and unpredictable" (p. 10).
} 
American thinking about Latin America itself. It lays the foundations for a prominent, multi-disciplinary dialogue and the constitution of a non-institutional intellectual collective of work. Composed of academic researchers residing in Latin America and the United States, it has a rising presence in Colombia, judging by recently published books from its perspective (Castro Gómez, 2005; Castro Gómez $\&$ Grosfoguel, 2007) and by the vitality of the journal Tabula Rasa, that also incorporates these points of view.

In active dialogue with contemporary intellectual tendencies such as postcolonialism, subaltern studies and world-systems theory (developed by Immanuel Wallerstein), $\mathrm{M} / \mathrm{C}$ differentiates itself from them by implicitly assuming (since sometimes this is not too explicit) a position of continuity with the traditions of Latin American critical thinking. Essentially, M/C organises itself from a critique of the historical-cultural and epistemological foundations of modernity, questioning its grand interpretivist narratives over the course of five centuries.

This great operation supposes, as a previous step, to "displace" the origins of modernity from its cradle in northern Europe, linked to the Protestant Reformation, the origins of the accumulation of capital, the Enlightenment or the French revolution, and draw attention to the "first modernity" in which a leading role was played by the Iberian kingdoms together with their expansion and overseas conquests. The movement results in a greater geo-epistemological importance as it allows for the visualisation of America as the first periphery of the European colonial system, the original hidden side of modernity. This perspective also entails verifying: a) the rationality of the forms of the State and Iberian colonial enterprises; b) the original accumulation of capital to those who authored these conquests; c) the appropriation of the natural biodiversity of the tropics as the foundation for modernity (Coronil, 2000); d) the emergence of the principles of the evangelising mission and European superiority as central articulations of the Eurocentric colonial imaginary, as a hegemonic common-sense that drives and justifies colonial enterprise, but also a "drive for identity", present in each individual subject of this project. 
For this critique, the narratives in question, which gave rise to all the epistemological geopolitics of the modern world (and, consequently, the genetic womb of the human and social sciences), ignore the significance of the colonial episode as a founding phenomenon of all the historic experience of modernity.Modernity would thus constitute a linear paradigm of historic evolution, instituting notions of "civilizing processes", "progress", or "development", which have been a unique experience, the heritage of a few European peoples (the northern European narrative, for example, is accustomed to excluding the Mediterranean in general, and the Iberians in particular, from this experience). For different reasons, which frequently include the biophysical inability of the non-European races to overcome natural conditioning, the rest of humanity was not capable of reaching this level of civilization, and its destiny was guided and driven by civilized peoples. This is what the theorists of the M/C Program call "eurocentrism" - an interpretation of history that attributes certain European peoples with an autonomous capacity for evolution and the construction of a history of the whole of humanity. Thus, it establishes a vast epistemology of geopolitical roots, a true "geographical imaginary" 5 that established, in reality, hidden relationships that continued for over five centuries. Paradoxically, this continuity (the geostrategic predominance of certain areas of the planet over the rest of the peripheral regions) is further highlighted when the analysis attempts to interpret historically determined periods or processes. Classic colonialism is, in general, excluded as an explanatory factor in these narratives. What attention was dedicated by the founding fathers of sociology, such as the French Durkheim or German Weber, to the colonial empires their countries had formed at the time in Africa? It is history that usually speaks of colonialism, but treats it as its own particular epoch, that ended with the political independence of the ex-colonies.

\footnotetext{
${ }^{5}$ Arturo Escobar (1996) uses this term, take from the Orientalism of Edward Said, to refer to the vision of the global world implicit in the conceptions of "developed/under-developed" that expand as the common sense of the epoch from the second half of the forties, in the post-WWII period, when the breakup of the colonial empires was imminent.
} 
Another case is the debate about globalisation. In the 1990s, during the golden years of neoliberalism, it was customary to characterise globalisation as an empire without a core, where national decisions and inequalities had ceased to exist, giving birth to a "global-centric" world (Coronil, 2000). "Global-centrism", for example, is the habitual place of enunciation of the Catholic Church, from the crusades through to the present. In March 2009, during a visit to African countries, the Pope invited the audience to abandon their tribal superstitions and witchcraft and adhere to the universal message of the Church. Partha Chatterjee, founder of the subaltern Indian studies group, proposes the necessary reverse of the "global-centric" discourse, what he calls "the rule of colonial difference that, following from the universal discourse, excludes the colonised as its beneficiaries. Chaterjee says:

This occurs when a normative proposition of supposedly universal validity (and many such propositions would be asserted in the centuries separating us from the early Portuguese expeditions) is held not to apply to the colony on account of some inherent moral deficiency in the latter. Thus, even as the rights of man could be declared in the revolutionary assemblies of Paris in 1789, the revolt in Saint Domingue (now Haiti) would be put down on the ground that those rights could not apply to black slaves. John Stuart Mill would set forth with great eloquence and precision his arguments establishing representative government as the best possible government, but would immediately add that this did not hold for India. The exception would not detract from the universality of the proposition; on the contrary, by specifying the norm by which universal humaneness was to be recognised, it would strengthen its moral force. In the case of the Portuguese expedition, the norm was given by religion. Later, it would be supplied by biological theories of racial character or historical theories of civilizational achievement or socio-economic theories of institutional development. In each case, the colony would be made the frontier of the moral universe of normal humanity; beyond it, universal norms could be held in abeyance (Spanish: Chatterjee, 2008: 30-31; English: Chatterjee, 1998: 1331)

The global-centric perspective recovers the discursive devices of colonialism and proclaims universal modernity as a fatal destiny, prophesied, for example, by Anthony Giddens.

From his perspective, it is no longer an issue of the West, as modernity is everywhere. The triumph of modernity lies precisely in having become universal. This could be called the 'Giddens Effect': from now on, modernity is the only way, everywhere, until the end of time. Not only is radical alterity expelled forever, expelled from the realm of possibilities, 
but all cultures and societies in the world are reduced to the manifestation of European history and culture (Escobar, 2005b: 68).

According to the theorists of the M/C Program, these would form the broad, hegemonic outline of an interpretation of the history and evolution of global societies, produced from a Eurocentric perspective, that attributes Europe with having instituted modernity and erects it as an explanatory-interpretive referential model for all valid historical and social logic. This perspective includes the social sciences, whose fundamental paradigms, established in the 19th century, comfortably excluded the consideration of those phenomena linked with colonialism, plainly still in force in this era (other symptomatic silences were, for example, the topics of gender and nature). And this criticism continues to be valid and applied, according to $\mathrm{M} / \mathrm{C}$ authors (including the most critical views, developed from European experience, such as Classical Marxism, ${ }^{6}$ Western Marxism and poststructuralism).

The M/C program is not defined in opposition to modernity, nor does it deny the emancipatory potential that it could possess. Its perspective is, in any case, "transmodern" (Dussel, 2000), assuming a critical distance in relation to those consecrated and consecrating narratives. Finding its locus of enunciation and epistemological foundation "in the margins", $\mathrm{M} / \mathrm{C}$ presents itself as "border thinking", which questions North-Atlantic modernity and asks about alternative paths and logics.

The interpretive apparatus of the M/C Program lies in a series of calculations that are derived from their characterisation of coloniality as a necessary, opposed and systematically hidden complement to modernity. The abominable (in a word) character of colonialism thus lies separated from modernity, which proceeds to assume an almost angelic character (somewhat like the "God without intestines" of which Kundera speaks). Therefore, the challenging part of the M/C program is located in a point of rupture with the equivalent chapter XXIV of Capital when Marx,

\footnotetext{
${ }^{6}$ See the following note about the heterodox reading of Marx by Claude Lévi-Strauss.
} ** 
attacking the sweet fables of the Political Economy about the natural origins of the categories of the mercantile economy, introduces into his narrative, as an eruption, an analysis of a historical perspective of original accumulation, where capital was born and was constituted by violent methods: "dirty with blood and mud."

In assuming this point of view, that is to say, processing the so-called "decolonial turn", an epistemic diversity emerges that allows us to discover a plurality of places of development, past and present, in critical relation or resistance to colonial modernity. This is why we speak of "border epistemologies" (Mignolo, 2007) from which one can construct diverse challenges to (or, eventually, partial recuperations of) modernity and coloniality. This entails a rewriting of the narratives of modernity from another space, revaluing dominated cultures and peoples and their stories of resistance. In the same way, it would be possible to once again tell a history of the continent, from the perspective of society/nature relations.

\footnotetext{
7 It is worth remembering a surprising text by Claud Lévi-Strauss, that no only offers an unusual reading of this chapter of Marx's Capital, as he advances (in 1961) a perspective that sits in dialogue with the M/C Program. "Thus, colonization historically and logically precedes capitalism, and the capitalist regime consists in treating Western people as Western people had previously treated native populations. For Marx, the relationship between capitalist and proletarian is thus only another particular case of the relationship between colonizer and colonized. From this point of view, one could almost maintain that, in Marxist thought, economics and sociology first appear as offshoots of ethnography. It is in Das Kapital that the thesis is put forward with perfect clarity. The origins of the capitalist regime go back to the discovery of gold and silver regions in America; then on to the enslaving of the natives; then to the conquest and looting of the East Indies; finally to the transformation of Africa into 'a sort of commercial preserve for the hunting of black skins. Such are the idyllic means of primitive accumulation which announce the dawn on the capitalist era.' Immediately afterward the mercantile war is declared. 'The mute slavery of the New World was needed as a cornerstone on which the covert slavery of Europe's wage earners was built."'
}

Lévi-Strauss continues: "In the first place, those societies which today we call "underdeveloped" are not such through their own doing, and one would be wrong to conceive of them as exterior to Western development or indifferent to it. In truth, they are the very societies whose direct or indirect destruction between the sixteenth and the nineteenth centuries have made possible the development of the Western world. Between them there is a complementary relationship. That same development and its greedy requirements have made these societies such as they are today" (Spanish: Lévi-Strauss, 1976a: 319-20; English: Lévi-Strauss, 1976b: 315). 
Perhaps it would be opportune to outline here, within the theoretical Marxist tradition, that the emergence of the themes of the coloniality of peripheral peoples and nature is present within the rupture made by Rosa Luxemburg. In the notes for her course Introduction to Political Economics, which she dictated in the cadre school of the German Democratic Socialist Party and her book The Accumulation of Capital, written in 1913, she incorporates an ample lesson, unusual in her time and place, about what would later be called the Third World. Not only that (and what makes this a valid predecessor of the contemporary $\mathrm{M} / \mathrm{C}$ perspective), this incorporation was expressed as "border epistemology" (and it is tempting to speculate over the possibility of "another point of reading" residing in the condition of her gender, which made her especially sensitive to alternate readings of the white, civilised, masculine hegemonic logics). Coloniality, says Rosa, is a constituent part of the accumulation of capital, its necessary and foundational obverse. Based on this insight, Rosa questions the analytic model of the capitalist mode of production developed by Marx in Capital, which does not incorporate the colonial subordination of people and nature as a necessary condition for the ample reproduction of this productive regime. We can see it in her words, in the last page of Chapter 31 in The Accumulation of Capital:

Thus capitalist accumulation as a whole, as an actual historical process, has two different aspects. One concerns the commodity market and the place where surplus value is produced - the factory, the mine, the agricultural estate. Regarded in this light, accumulation is a purely economic process, with its most important phase a transaction between the capitalist and wage labourer. In both its phases, however, it is confined to the exchange of equivalents and remains within the limits of commodity exchange. Here, in form at any rate, peace, property and equality prevail, and the keen dialectics of scientific analysis were required to reveal how the right of ownership changes in the course of accumulation into appropriation of other people's property, how commodity exchange turns into exploitation and equality becomes class-rule.

The other aspect of the accumulation of capital concerns the relations between capitalism and the non-capitalist modes of production which start making their appearance on the international stage. Its predominant methods are colonial policy, an international loan system-a policy of spheres of interest—and war. Force, fraud, oppression, looting are openly displayed without any attempt at concealment [...] The conditions for the reproduction of capital provide the organic link between these two aspects of the 
accumulation of capital. The historical career of capitalism can only be appreciated by taking them together (Spanish: Luxemburgo, 1967: 351; English: Luxemburg, 2015: $432-433)^{8}$

For some, such as one of the pioneers of environmental history, Professor Donald Worster from the University of Kansas, this history is an answer to the environmental worry that has been growing in public opinion during recent decades. Others, such as the economist James O'Connor, from the University of California, are much more radical: in the face of an offensive by global capital to appropriate and commodify all the world's natural resources, environmental history becomes the history of our age, and all past history can and now much be told as environmental history. ${ }^{9}$

The field of environmental history is growing in Latin America, with the Latin American and Caribbean Society for Environmental History (Sociedad Latinoamericana y del Caribe de Historia Ambiental—SOLCHA) already having held five meetings. It is a space for intellectual reflection that offers particularly stimulating multidisciplinary encounters between researchers from the entire region.

This Latin American reflection, at the same time, has interesting international repercussions. In particular, there are many exchanges of perspective with the production of the United States. In effect, the territory that came to be known as

\footnotetext{
${ }^{8}$ Over the course of previous chapters, Rosa Luxemburg develops a history-based analysis of the destruction/recomposition of the social forms of colonial peoples, but what is especially interesting is its relevant treatment of the transformation of nature into commodities, which also constitutes a precedent to political ecology and environmental history. A contemporary recuperation of Rosa Luxemburg's perspective can be found in Harvey (2004).

9 O'Connor says: "environmental history may be regarded as the culmination of all previously existing histories-assuming we include environmental dimensions of contemporary political, economic, and cultural history, as well as environmental history strictly defined" [...] "Environmental history is, in short, the history of the planet and its people and other species' life and inorganic matter insofar as these have been modified by, and have enabled and constrained, the material and mental productions of human beings [...] Since these relationships are indecipherable without an investigation of the social relations between human beings ('society,' 'economy'), on the one hand, and nature's own (modified, stunted, enhanced) biological, chemical and physical relations, on the other, the scope of environmental history is, for all practical purposes, limitless [...] In principle, environmental history is a totalizing history, the only true 'general' or universal history" (Spanish: 2001: 74 and 78; English: 1998: 51 and 54). It is pertinent to clarify that this extreme position of $\mathrm{O}^{\prime}$ Connor is substantiated over the course of the article.
} 
"America" was the stage of what was perhaps the greatest succession of environmental catastrophes in human history: invasions of humans, animals, vegetable species, and diseases that devastated and subdued the original populations. It was a North American historian, Alfred Crosby (1993) who wrote one of the available stories about this assassination. It seems to us that residing in this original trauma is the key question to think about the problem of coloniality of the environment and the underdevelopment of Latin American societies.

Another important work, also produced in the United States, is the book Late Victorian Holocuasts by Mike Davis (2000), which is defined specifically as a book about political ecology, analysing the great droughts that affected the tropical regions of the world in the last quarter of the 19th century, sparking great famines and death tolls. In the first part, Davis analyses the oscillations of the Pacific Ocean currents (the phenomena of El Niño and La Niña) and its effects on the pattern of winds and rains in the inter-tropical region. Later, he demonstrates that the effects of these climactic changes were heightened in the tropical region that, at the time, was experiencing the processes of imperial penetration that had disarticulated traditional peasant economies and established the separation of subsistence agricultural production and the orientation toward external markets. A fundamentalist freemarket ideology prevailed among colonial authorities, which postulated the need to allow "natural" forces to re-establish equilibrium.

As a result, proposes Davis, more than the millions of lives sacrificed, the affected regions were left prostrate, and imperial order was easily imposed on them. Here would be the origin of the current "Third World".

The prestigious historian Donald Worster proposes a classical definition of environmental history: "environmental history occupies the role and place of nature in human lives. It studies all interactions that societies of the past have had with the 
non-human world, the world that we have not created in any primary sense" $(2003: 25){ }^{10}$

I must say that this definition always makes me feel slightly uncomfortable. In the first place, it seems to separate nature and culture too radically, rendering invisible certain important questions, which Worster does not deny. Human action transforming the natural environment creates more environments, a "second nature" (or "third" or "nth") that is a human creation, but that evidently behaves as if it were composed of natural ecosystems (cities, agriculture, etc.). From this point of view, human action also creates new relations within nature.

Secondly, those elements of human ecology also depend on the combined actions between social and natural relations. The spatial distribution of specimens of a species is part of the ecology of that species. "Why are there black and white people in the Americas?" an extra-terrestrial visitor could ask. Obviously because there had been conquest and slavery. Therefore, the current population of the Americas is not understood, from a biological perspective, without reference to non-natural historical processes. That is to say, the distribution of specimens of the human species throughout the continent (an object of human ecology) refers to a complex interaction, historically given, between power relations and social domination.

The demographic significance of humans of extra-American descent is only explained by the radical process of depopulation of original inhabitants, in which a principal role way played by pathogenic agents of disease, brought over by the Europeans. This depopulation reached $90 \%$ in the first century of conquest and created the need for black slavery. Thus, natural elements, unintentionally driven by humans during an undertaking of conquest and subjugation, acted on aboriginal societies, bringing about their destruction almost to the point of annihilation. Therefore, this does not

${ }^{10}$ A disciple of Worster and one of the Latin American precursors of environmental history, the Panamanian Guillermo Castro Herrera gives a highly suggestive definition: "environmental history could define itself as the investigation of the consequences in the Latin American territory, derived from processes of transformation of the natural biospherical environment, associated with successive development styles in the region" (1996: 31). 
merely deal with a society/nature interaction, but complex relations between humans, which include violence and power, mediated by natural elements.

To offer another example: the Australian historian Elinor Melville (1999) studied the case of the destruction of a prosperous Indigenous agricultural region in Mexico, el Valle del Mezquital, by the flocks of sheep brought over by the Spanish. The narrative of environmental history presented by Melville recounts the destructive interaction between natural elements, which were provoked by established unequal power relations between humans. This natural catastrophe, in turn, either redresses the unequal relations between humans or establishes new ones. "Sheep are devouring men," said Thomas Moore of the enclosures in England. Indeed, but there are also people behind the sheep...

The case of the conquest of the Americas (and Oceania, some centuries later) is an evident example of a mega environmental catastrophe from human intervention, given they were territories that were isolated from the great Euro-Asian-African block. Nevertheless, it is still relevant to think of the whole of human history as a co-evolving relationship with natural systems. Another North American historian, Stephen Pyne (1997) puts forward the hypothesis that the great plains of the western United States were the product of centuries of human action, that destroyed the original forests. Similarly, based on the work of the great Brazilian geographer Azis Ab'Saber, from the University of São Paulo, and the North American anthropologist Darrel Posey, one tends to think of the joint development of the Amazon Jungle and human societies. In summary, without entering into a specialised discussion, it seems unarguable to me that human action on the environment was producing a humanised nature long before any historic records began.

I wish to propose, therefore, another definition of environmental history: it is the study of the interaction between human societies and the natural environment over the course of time, and its consequences derived from both, including natural interactions mediated by humans and human interactions mediated by nature.

I believe that there are various dimensions contained within the intellectual proposal of environmental history that have important meaning for ecological debates and 
conflicts that are currently underway in Latin America. I will attempt to briefly recount them.

Despite its emphasis on the materiality of history, in its search for antecedents, environmental history separates itself from Marxism, at least the classical, "canonical" versions. ${ }^{11}$ The mainstream Marxist tradition always attributed a positive sense to the development of productive forces, generally interpreted as a markedly mechanical form, without taking into account all of its dimensions. Marxism shared with all 19th century science (and a large part of current scientific thought) the optimistic idea that science and technology would domesticate nature, and that it would always be possible to find technical solutions to problems, an idea that environmental thinking rightly puts in doubt. In this way, the confluence of Marxist politics and developmentalism was quite common in Latin America. Environmental history, to incorporate problematic dimensions that developmentalist perspectives left out of their analyses, called attention to the hidden costs of processes that at times have been glorified by economic history. Many economic successes of Latin American history can now be read as disasters (and Amazonian history, in particular, has many examples to show for itself).

For example, an environmental perspective, oriented to evaluating the balances of energy in nature, arrives at the conclusion that the agricultural model of the "green revolution" has failed, and now consumes more energy than it produces, especially that which is sourced from non-renewable fossil-fuels. Many more have failed if we include in this evaluation an account of resources that includes the cost of erosion, biodiversity loss, or land fertility contaminated by agricultural chemicals, etc. All of this is without considering the social and human costs of establishing industrial agriculture, in the form of the dispossession of campesino land, loss of employment

\footnotetext{
"Of course, the topic of the environmental concerns of Karl Marx himself is a topic for discussion. Without a doubt, in the margins of the Marxist tradition one finds important reflections for an environmental perspective on history. For example, the work of Nikolai Danielson, who, in Russia at the end of the 19th century, perceived that the destructive dimensions of capitalism could be greater than its constructive ones and finally block the dynamics of its own progress (Alimonda, 2006).
} 
and market for agricultural families, effects on the health of the rural population, rural exodus, the growth of cities, etc.

From the 19th century, in the Argentine pampas or the prairies of the US and Canada, grain was produced in fantastic quantities, capable of feeding many generations of human beings and generating enormous wealth in those countries. At the same time, the natural fertility was lost, and animal and plant species became extinct; there were, and still are, enormous problems of erosion and desertification. But this irreparable environmental damage was never counted in the cost of this production. All of this is repeating itself, amplified, with the case of genetically modified soy that currently accounts for $70 \%$ of tilled land in Argentina (La Nación, 28 August 2010). ${ }^{12}$

Following the Argentine case, there is another interesting example of how economic history, in privileging histories of success, proceeds to create spatial segregations, leaving histories of failure out of sight, which are themselves recovered by environmental history. From 1860, the humid pampas of Argentina experienced an intense process of development oriented toward exportation, with an enormous accumulation of capital, transatlantic migration, construction of railways and public works, urbanisation, etc. But behind that process, a vast region of dry subtropical forest, the Chaco of Santiago and Santa Fe, were destroyed. Its mountains contained quebracho, a tree whose wood is hard and resistant to the elements and was primarily used for railway sleepers and telegraph poles. However, the economic history of Argentina dedicates thousands of pages to the success of grain and meat (in whichever form, without taking into account its environmental impact on the humid pampas themselves) and has nothing to say on the destruction of the forests of Santiago del Estero, which was transformed into an arid region, with chronic environmental and social problems.

Here, territorial hegemonies and subaltern regions appear particularly important. Coloniality did not end with what the historiography of our countries calls "the

\footnotetext{
${ }^{12}$ At this point, there is ample critical literature. One could consult Domínguez and Sabatino (2006), Pengue (2008), and the work of the tenacious campaign of the Rural Reflection Group.
} 
colonial period". In every Latin American country there are regions that, for a variety of reasons (be they geomorphological, climactic, etc), presented difficulties when being incorporated into territories for the effective exercise of power for the colonial administrations, whether for disinterest, costs not matching benefits, or characteristics making difficult the establishment of a metropolitan population as a nucleus. ${ }^{13}$

This is what Germán Palacio (no date) highlights, with reference to the Amazon but which is valid for these regions: their eccentricity. It is the case of the Amazon and all the countries it spans, the Pampa of Patagonia, the Chaco in Argentina, the Araucanía in Chile, the North and Yucatan in Mexico, the Petén in Guatemala, the Darién in Panamá, and the 'lowlands' in general in Colombia. These regions are incorporated into territories of independent States, often unexplored and unknown, from which derived the conflicts over the demarcation of borders during the course of the 20th century. Indigenous peoples subsist or find refuge within them. Against these peoples, national armies, when political and technological conditions permit (railways, repeating firearms, telegraph, etc.), develop programs of conquest and subjugation. In Argentina, the "Conquest of the Desert" was justified by Estanislao Zeballos as necessary to complete works left unfinished by the Spanish. He was going to repeat, in relation to the indigenous peoples of the Pampa and Patagonia, a war of conquest. The great advance of the Argentine army to the Río Negro was conducted in 1879, and the fight continued for several more years in the mountain ranges of Neuquén. In 1883-84 the campaign of the Chaco was fought. At the same time, the Chilean army completed the so called "Pacification of the Araucanía" against the Mapuche. The fight against the indigenous of Mexico occupied the entire second half of the 19th century. Operations against warrior peoples of the north, such as the Apaches and Yaquis lasted until the end of the 19th century, and the so called "Mayan Wars" only finished in 1904, with the surrender of the rebel city Xan Santa Cruz.

\footnotetext{
13 Along these lines, the important work of Serje (2005) on Colombia, supports elements that can be applied to all countries in the region. It seems perfectly justified to include this reflection on the natural environment and the formation and exercise of political power in the bibliography of Latin American political ecology.
} 
But the Mexican army also confronted local, autonomous campesinos, the most famous of which was the Tomóchic rebellion in the state of Chihuahua, from 18911892 (Alimonda, 2002a). Brazilian equivalents were the Canudos conflict in the interior of Bahía (1893-1897) and the Contestado War in Santa Catarina (19131915), where the national army conducted ruthless campaigns against autonomous campesinos, which had not submitted to the territorial authority of the republican government.

Incorporated into the national order through conquering military operations, these regions generally lacked the autonomy enjoyed by political units where territorial hegemony was exercised by dominant local classes. They depended directly upon the powers of the national executive, in a regime that could be described as "internal colonialism", that presupposed occupation and management by administrative and military organs of the central government, such as surveys of natural resources and their "implementation value" according to the logics and needs of the hegemonic regions.

In Argentina, for example, a formally federal country, according to the constitution of 1853, the areas conquered from the indigenous groups after independence (that is, more than half of the land-area of the country) remained until roughly 1950 as "national territories", ${ }^{14}$ dependencies of the central power and deprived of the federal attributes of the " 14 provinces" that protect their autonomy, as negotiated by the local oligarchs with the central authority.

Hence the second characteristic, derived from coloniality, that Germán Palacio attributes to these regions-asynchrony. Their history does not follow, not even slightly, the stages of the national societies into which they have been incorporated. As lucidly expressed at the time, by Argentine Estanislao Zeballos, the independent nation state was finishing, during the course of the 19th and 20th centuries, the conquest and territorial occupation the Iberian colonisers had left incomplete. In

\footnotetext{
14 These include the current provinces of La Pampa, Río Negro, Neuquén, Chubut, Santa Cruz, Tierra del Fuego, Chaco, Formosa and Misiones, created during the first government of General Perón (1946-1952).
} 
order to continue the history of these regions, therefore, it is necessary to add tension to these established narratives.

Let us note that here we have an important point of contact between the environmental history perspective and the Modernity/Coloniality Research Program. The "decolonial turn" is complemented by a "natural-colonial turn". It attempts to read and narrate the epic of modernity through its obverse, from its silenced dimensions. If the perspective of the M/C Program entails the recuperation of silenced discourses, environmental history also seeks out its hidden voices, consequences that are neither assumed nor confessed, environmental and social destruction that the exemplary processes of development occlude, which are frequently revealed to be unsustainable.

Returning to the topic of antecedents, if environmental history diverges from the Marxist tradition, it instead vindicates a precursor that was formed in this traditionKarl Polanyi (1886-1964), a Hungarian linked to the Austrian Social Democratic Party. With the ascension of Nazism and incorporation of Austria into the Third Reich, Polanyi was exiled to England and later travelled to the United States and Canada, where he developed his academic career. It is interesting to note that, despite large affinities with both his academic career and personal views, Polanyi always took care to differentiate his work from Marxism or, in any case, hide these affinities (an effect, perhaps, of his need to circulate in the Anglo-Saxon academic sphere during the Cold War). ${ }^{15} \mathrm{He}$ Wrote an important work that was recovered during the 90s by critics of the neoliberal boom.

His best-known book, The Great Transformation, was published in 1944. There, Polanyi asks after the origins of the terrible crisis and war humanity was navigating. His conclusion was that this catastrophe was the result of the uncontrolled expansion of market liberalism since the middle of the 19th century (globalisation, we would say today). At the same time as it had multiplied wealth and technology to levels previously unseen, this expansion introduced the entire planet into a market system

\footnotetext{
${ }^{15}$ It seems improbable, with his political trajectory and intellectual development, that Polanyi did not know of the works by Rosa Luxembourg.
} 
based on a central fallacy: to consider as commodities, to produce as commodities, two central elements of the real world-nature and the work force (which he called fictitious commodities). Market fundamentalism, built atop this double fiction, provoked the disaggregation of all established societies, the multiplication of social and political crises, the need for repressive internal systems, and the international arms race. The final results were the lack of solutions, authoritarian recompositions, and war.

Chapter fifteen of The Great Transformation is called Market and Nature. Polanyi demonstrate that what today we call "land" was always inextricably linked with all the complex dimensions that constituted human societies. In reality, he says, to suppose that nature was just "land", that it could be subject to purchase and sale in the market in exchange for money, was once a utopia with no connection to reality. But it is better to offer his words:

Traditionally, land and labor are not separated; labor forms part of life, land remains part of nature, life and nature form an articulate whole. Land is thus tied up with the organizations of kinship, neighborhood, craft, and creed - with tribe and temple, village, guild, and church. One Big Market, on the other hand, is an arrangement of economic life which includes markets for the factors of production. Since these factors happen to be indistinguishable from the elements of human institutions, man and nature, it can be readily seen that market economy involves a society the institutions of which are subordinated to the requirements of the market mechanism. The proposition is as utopian in respect to land as in respect to labor. The economic function is but one of many vital functions of land. It invests man's life with stability; it is the site of his habitation; it is a condition of his physical safety; it is the landscape and the seasons. We might as well imagine his being born without hands and feet as carrying on his life without land. And yet to separate land from man and to organize society in such a way as to satisfy the requirements of a real-estate market was a vital part of the utopian concept of a market (Spanish: Polanyi, 187; English: Polanyi, 2001: 187).

Nature, linked in every way to the life of society, was transformed into mere "land". And with this movement social equilibriums that had been constituted over centuries and were the basis for social imaginaries were disarticulated. This process, that occurred all over the world, has affected and continues to affect Latin American indigenous populations and be present in campesino resistance in defence of their lands, including movements in all countries along the Andes that oppose large-scale 
mining. The defence for and respect of Pachamama, the central proposition of the Andean concept of "buen vivir", present in the recent constitutions of Ecuador and Bolivia, is directly linked to the effort to protect nature and exclude it from the market.

For Donald Worster, this process of commodifying nature was as revolutionary and devastating as the Neolithic revolution. Here there exists, according to his perspective, a privileged topic for environmental history:

I submit that the single most important task for scholars in the history of modern agroecology is to trace what Karl Polanyi has called "the great transformation," both in general planetary terms and in all its permutations from place to place [...]

What actually happened to the world of nature, once it had been reduced to the abstraction "land," is one of the most interesting historical problems presented by the capitalist transformation and will require a great deal more research by environmental historians. There are many possible lines for that research to take, but among the most promising is an inquiry into the restructuring of agroecosystems that capitalism promoted. First in England and then in every part of the planet, agroecosystems were rationally and systematically reshaped in order to intensify, not merely the production of food and fiber, but the accumulation of personal wealth. (Spanish: Worster, 2003:3335; English: Worster, 1990: 1097-1101).

Worster gives central importance in his formulations to Polanyi's idea that the transformation of nature into land constituted a milestone in human history. From his perspective, it is not strictly the sale of production in the market, which can also occur in subsistence agriculture, but the process of a comprehensive reorganisation of agriculture for that purpose. A specialised agriculture that produces surpluses of certain types of products supposes a radical simplification of agricultural ecosystems, with the consequent loss of biodiversity and a greater vulnerability of the entire agricultural complex, as much from an ecological standpoint as economic-financial and energetic.

There is a different nuance here that constitutes another discrepancy between environmental history and interpretations of Marxist inspiration. The process of reorganising production by orienting it toward distant markets has more explanatory importance than the question of relations of production, central to the Marxist 
tradition. If the so-called "Atlantic Forest" of Brazil was destroyed to plant sugar or coffee, from an environmental standpoint it matters little whether the workforce used were enslaved or salaried.

What had once been a biological community of plants and animals so complex that scientists can hardly comprehend it, what had been changed by traditional agriculturalists into a still highly diversified system for growing local foodstuffs and other materials, now increasingly became a rigidly contrived apparatus competing in widespread markets for economic success. In today's parlance we call this new kind of agroecosystem a monoculture, meaning a part of nature that has been reconstituted to the point that it yields a single species, which is growing on the land only because somewhere there is strong market demand for it (Spanish: Worster, 2003:35; English: Worster, 1990: 1101).

Worster does not fail to highlight that, along with the disappearance of biodiverse agriculture, there is also a loss, a closure of the peasant knowledge associated with it. Humans that interact with monocultures are imprisoned, in some ways, by a unique, highly specialised knowledge, and have lost the detailed abilities and knowledge of nature that allow for multicultural agroecological practices.

Another strategic dimension is how environmental history comes to fuel contemporary debates that Catalan economist Joan Martínez Alier (2004) call "environmentalism of the poor" and we prefer to call "popular environmentalism". It attempts to identify how, as there are environmental movements for "the rich", which originate in informed environmental concerns, there are also popular movements that mobilise for environmental reasons, even if they do not carry the same name. Fortunately, this is a subject that is readily evident in Latin America, and it does not need to be reaffirmed. However, merely a few decades ago it was common to hear the dismissal of environmentalism by conservative voices, for being "imported", "chic", etc.

The perspective of environmental history, therefore, also allows another reading of these movements and, by extension, of all Latin American History. In the 20th century, the environmental movement appeared and identified demands, conflicts, and specific movements. But these demands, conflicts and movements had always 
existed throughout history, although their environmental components had not always been explicit in the conscience and discourse of the actors involved.

At this point, we re-encounter Rosa Luxembourg and Karl Polanyi. If the decisive factor in the origins of the market economy is the transformation of human beings and nature into "fictitious commodities", then the resistance against these commodifying processes takes on a new significance. It is not merely resistance in the name of halting progress, as asserted by the hegemony of liberal enlightenment and traditional Marxism. It is possible to now read them as forms of resistance based in the defence of traditional systems of social organisation for the use and communal availability of human and natural resources, in the face of attacks by commercialisation.

An entire tradition of good English historiography has been applied to reconstruct popular resistance during the time of the Industrial Revolution, in the form of a defence of the "moral economy", in which a collective ethic presided and regulated social and environmental relations in the name of preserving basic values of cohabitation. The same logic is being applied for the interpretation of the historic formation of Latin American countries. This allows us to trace genealogies and continuities between the fights of indigenous peoples during five-hundred years of their history and current conflicts and challenges. It does not attempt to rewrite all history and environmental conflict, but recognises the presence of these dimensions, although they were not explicit, in different moments and processes of our past. If the decisive theme of environmental history, as proposed by Worster, is the process of commodification of nature and forms of popular resistance, we find a bridge between the past and present. The current global resistance movement, with all of its difficulties and contradictions, or contemporary indigenous or environmental movements, acquire concrete roots and profound legitimacy in our past and in our identities. 


\section{Political Ecology}

But in addressing these political dimensions of environmental history, we are approaching another intellectual field of contemporary relevance in the social sciences: political ecology.

In fact, people began to speak of political ecology in the 1970s, in reference to a series of pessimistic predictions of a markedly conservative and neo-Malthusian character, which visualised limits for the industrial development model and received quite an orthodox critique by Hans Magnus Enzenberger in his book Para una crítica de la ecología politica (Toward a critique of political ecology) (1974).

Subsequently, political ecology was configured, in its academic perspective, as a field of confluence and mutual feedback between different social sciences. In the English anthropological tradition, it had been, on the one hand, a politicisation of a traditional problem area-human ecology—that came to incorporate political dimensions into its analysis. On the other hand, a series of works produced by geographers, who studies ecological topics (such as soil erosion, deforestation, use of water, etc.), were arriving at the conclusion that it was not possible to understand these problems if you did not include political dimensions. It affirmed the conviction, encapsulated by David Harvey, that "all ecological projects (and arguments) are simultaneously political-economic projects (and arguments) and vice versa" (cited in Bryant \& Bailey, 1997: 28).

Let us indicate here the fundamental difference in relation to the field of environmental history, despite how closely aligned its problematic concerns are with political ecology. Epistemologically and methodologically, environmental history is located within the disciplinary boundaries of history, and it is there that it is fighting for recognition. Political ecology, in contrast, critiques in its practice the exacerbated compartmentalisation of technical and technologized knowledge, and highlights, on the contrary, the necessary integration of perspectives to account for its objects of study. Pragmatically, in a recent book a British geographer has said:

Political ecology can be understood as a kind of umbrella, under which coexist various traditions and lines of political and ecological research that share certain ethical- 
political and intellectual concerns [...] the field of political ecology emerged and was constructed under the notion that it is not a theory, but a common space of reflection and analysis, largely defined by its own history and by those who practice it, who share a vision more or less similar of ideas and practices which sustain it (Bebbington, 2007:26).

Against this, an "expanded" and ambitious version of political ecology is presented by the noted French intellectual and politician Alain Lipietz, deputy for Les Verts in the European Parliament. Firstly, for Lipietz, political ecology is, at the same time, a totalising perspective of scientific knowledge and a reformist political practice. It is clearly understood here as homologous with Marxism, and Lipietz makes this explicit. Facing the crisis of Marxism, political ecology would reassume some central legacies (materialism, the dialectic, the notion of crisis), while leaving behind unsustainable hypotheses (the belief in the virtues of developing productive forces, the glorification of technology, the working class as the revolutionary subject).

For Lipietz, the basic characteristics of the human genre of ecology is its political character. Humanity produces and reproduces its subsistence collectively, which necessarily implies that its relationship with the natural environment is always mediated by social relationships of domination and consent. What to produce, how to organise labour processes, how to distribute surpluses, and the ends to which they are destined are all necessary decisions that refer to situations of domination and consent. At the same time, human communities are organised in territories, which presupposes disputes or cooperation between territorial communities. In sum, if the ecology of the human race is political, the logical development of Lipietz's argument leads to the configuration of scientific political ecology as a totalising point of view, which interpolates and integrates all of the sciences, whether they be oriented toward the study of nature or directed toward the study of human societies (1999, 2002, 2003).

Curiously, those of us who have tried to approach a conception of political ecology in the Spanish tradition have coincided in seeking a different approach from the Lipiezian totalisation or, at the same time, the pragmatic English umbrella. The one 
who introduced the notion of political ecology into our language was Joan Marínez Alier, author of a solid and informed work and founder and editor for fifteen years of the journal Ecología Política, published in Barcelona, and which constituted an obligatory reference for these topics.

Martínez Alier came to realise a critical lesson from the intellectual tradition of political economy, highlighting its systematic and symptomatic silences in relation to the question of nature and recovering authors who, in isolation, were constituting a reflection on ecological economics. In relation to the continuation of this critical work and the recognition of the antecedents of political ecology in English anthropology and geography (limited, in any case, by a functionalist method that, in reality, was not intrinsic and reduced its reach to the local level), he proposed as its object of study distributive ecological conflicts.

"Ecological distributions," proposes Martínez Alier, "are understood to be social, spatial and temporal patterns of access to obtainable benefits of natural resources and services provided by the environment as a system that supports life [...] In part, political ecology overlaps with political economy, in that the classical tradition is the study of conflicts of economic distribution" (2004: 104-105). Despite almost entirely incorporating political ecology within economics, Martínez Alier's point of view is not economistic, given its permanent reference to the dimensions of conflict and negotiation implied in the processes of ecological distribution and the different "languages of valorisation", sometimes untranslatable and incommensurate, of those who are the messenger of the different actors involved in these conflicts.

Another perspective was developed by the Colombian Arturo Escobar, stemming from the "interwoven character of the discursive, material, social and cultural dimensions of the social relations between human beings and nature". Thus, he prefers to avoid the society/nature dichotomy, seeking a definition of political ecology that "displaces nature and society from their privileged position in Western analysis." He therefore proposes that "political ecology can be defined as the study of the multiple articulations of history and biology, and the inevitable cultural mediations through which such articulations are established" (2005a: 24). "Political ecology has 
as a field of study the multiple practices through which the biophysical has been incorporated into history or, more precisely, those practices in which the biophysical and historical are mutually implicated" (2005a: 25).

However, some years before, ${ }^{16}$ Escobar had approached Marínez Alier's perspective and had explicitly opted to deepen it. Thus, in his introduction to the book Más allá del Tercer Mundo: globalización y diferencia (Beyond the Third World: Globalisation and Difference), he says: "Chapter 5 begins the prospective work of thinking about place, difference and globalisation from a broadly political ecology perspective. This chapter proposes a vision of political ecology that systematically incorporates the economic, the ecological and the cultural, defining this field as the study of economic, ecological and cultural conflicts of distribution. With this definition I extend the notion of political ecology proposed by Joan Martínez Alier to the cultural field" (2005b: 17). ${ }^{17}$

The recognition of plural knowledges and the need to deconstruct alternative rationalities is a key point in the perspective of the Mexican intellectual Enrique Leff. The exercise of power in the logic of accumulation and the market, at the same time as it fragments knowledge of a scientific and technological base and orients it unequivocally to its needs, has split it off from the vast field of popular knowledge of

\footnotetext{
16 The previously cited article by Escobar was published in English in 1999.

17 However, in the cited article, Escobar does not integrate these analytical dimensions into a structured political ecology. To the surprise of the reader, in the text of the article, political ecology only occupies one of the dimensions of distribution: "If economic distribution underlies the political dimension of the economy, giving rise to the political economy, and if ecological distribution identifies dominant economic strategies as sources of poverty and environmental destruction thus giving origin to the field of political ecology, cultural distribution therefore displaces the study of cultural difference from its strict relation to diversity toward the distributive effects of cultural predominance and, in turn, its surrounding struggles. This last aspect of our tripartite conception of distributive conflicts generates a political anthropology centred on the relationship between political power and contrasting cultural practices. Power inhabits meaning, and meaning is the source of power" (2005b: 130). With political ecology being limited to the analysis of economic strategies, and the specificity of the political field, it is diluted into a vacuum. It is true that power inhabits meaning, but power does not lie solely within meaning. **
} 
nature. Indigenous knowledge, based in centuries of coexistence, observation and empirical experimentation in the framework of local ecosystems, was discarded at the time of conquest and during the colonisation that has continued until the present day.

For this reason, Leff insists that political ecology supposes a political epistemology. Political epistemology overflows into an interdisciplinary project in its desire for integration and complementarity of knowledges, recognising strategies of power that play a role in the field of knowledge and reducing the environmental conflict to an encounter and dialogue of knowledges [...] Political ecology in Latin America is fuelled by perspectives originating from philosophy, epistemology, ethics, economics, sociology, law, anthropology and geography, ${ }^{18}$ by authors and social movements that, beyond the proposition of ecologising thought and action, are coming together in the political arena and in the study of power relations that crosscut knowledge, wisdom, being and doing. Proof of this is, between others, the environmentalisation of indigenous and campesino struggles and the emergence of Latin American environmental thought that supports proper reflection on these topics and processes (Leff, 2006: 32, 37 \& 38).

Finally, I want to note here that other authors have attempted to offer an account of a conception of political ecology that would be feasible from a practical point of view for research and knowledge generation and appropriate, at the same time for developing critical perspectives and establishing dialogues and negotiations, as much in the interdisciplinary academic sphere as in relation to actors in environmental conflicts. Recognising the relevance of contributions by authors such as Martínez Alier, Escobar or Leff, our reflections lead us to attempt to ground political ecology in a space of enunciation that, in any case, finds its place in the analytical body of political science.

In effect, before appearing as problems of distribution, it seems that the ecological questions of human societies constitute questions of appropriation, such as the establishment of power relations that allow for access to resources by certain actors, for decision making about their utilisation, for the exclusion of other actors from their availability. It is a matrix of social power relations that have prevailed in Latin America since the colonial period and were predicated on access to and control of

\footnotetext{
${ }^{18}$ It is curious that in this list, Leff does not mention history.
} 
land and other resources. This historical perspective, informed by environmental history, but also the economic, social and political histories of the region, deepens, it seems to us, the perspective of a political ecology constructed only from the present, privileging the reading of current environmental conflicts.

To turn to an example, it seems to us an overly short-term vision to analyse the emergence of "environmentalised" indigenous movements that cover the breadth of the Americas merely as a problem of "distribution", when in reality these conflicts have been configured over the course of complex processes of exploitation and exclusion for more than five centuries. In this case, behind the current "conflicts of distribution" lie long histories of coloniality, which entailed physical and cultural genocide, mechanisms of expropriation, and exclusion from natural resources, such as the destruction or racist subordination of identities.

Another important point to highlight is that the perspective of these authors tends to minimise the analysis of the role of the State and its policies in relation to the environment. ${ }^{19}$ It is true that it touches on a theoretical necessity, which has the healthy effect of highlighting the dynamics of local movements and, at the same time, serves to call attention to the presence and effect of both macro-powers acting in local public fields and implicit political common-sense often hidden in cultural distinctions, for example.

The State, however, through its multiple mechanisms (the Law, to start with), its institutions, its visible and invisible policies, its routines, is the Great Primary Distributor that underlies current conflicts of distribution. It is also the one who establishes general macro-political lines of environmental management in subordinated territories. In that sense, taking up the classical perspective of the work of Henri Lefebvre, a line of investigation of contemporary English geography, tends to think of the State as the great (re)organiser of territorial spaces, and baptise it as the "Ecological Leviathan" (Whitehead, Jones and Jones, 2006).

\footnotetext{
19 Arturo Escobar appropriately uses the Foucauldian notion of "governmentality" in his analysis, and particularly claims the importance of the State, although never dedicating particular attention to it (2005b: 134).
} 
These examples seem pertinent to us in order to reformulate a vision of Latin American political ecology that bestows a central place to "the political", at the same time as it can account for its porousness and contradictory character. Thus, just as Martínez Alier proposes a political ecology that overlaps, in part, with political economy, from our point of view, we wish to propose a political economy that superimposes itself on the problematic field of political science (understood not as "the science of the State", in its classical conception, but as the study of the formation of hegemonic power and deviant counter-powers, a political science that puts authors such as Gramsci or Mariátegui in dialogue with the environmental issues of our age).

Without any sort of previous agreement, my friend Germán Palacio and I have arrived at these points of view. Thus, each one of us has, at the same time and of his own accord, attempted to write alternative definitions of political ecology that privilege the political space. I present here an attempt at a definition of political ecology: it is the study of the complex and contradictory articulations between multiple practices and representations (including different systems of knowledge and topological devices), through which diverse political actors, acting at similar or different scales (local, regional, national, global) are made present, with relevant effects and with differing grades of legitimacy, collaboration and/or conflict, in the constitution of territories and in the management of their endowments of natural resources. ${ }^{20}$

Germán Palacio, for his part, after reviewing several antecedents, including James O'Connor, Martínez Alier, and the English-language bibliography, concludes that:

[...] all of these proposals are founded in approaches that do not give primacy to politics, as such, but the sources of political power, that is to say, to the economy, or society and its classes and forms of organisation. This conceptual relegation of politics occurs in other studies that are recognised as political ecology. Therefore, I propose that Ecopol is an inter-and trans-disciplinary field of discussion that reflects upon and discusses power relations in relation to nature, in terms of its social fabrication, appropriation and control by different socio-political agents [...]. Similarly, political ecology discusses the

\footnotetext{
20 This definition clearly includes, in the Gramscian tradition: a) culture, as an inseparable part of the political (Álvarez, Dagnino \& Escobar, 2000); b) the political not supposing automatic consensus, but constitutive antagonisms (Mouffe, 2000).
} 
aspects of social fabrication, construction or systematisation of nature, not only in terms of material issues, but its imaginary or symbolic construction. Thus it includes the ways in which society, on the one hand, and science, on the other, imagine or invent notions of nature and what are considered environmental problems [...]. Such an Ecopol recognises the support of political economy in the way it analyses processes of appropriating nature, by which it reviews its circulation, distribution and consumption. From there, modalities and disputes are derived around the appropriation, usufruct and control of nature. Consequently, the disputes, struggles and negotiation of these agents are also analysed, from which the political-economic problems of environmental justice are derived (Palacio, 2006: 11).

\section{The Coloniality of Nature}

With our comments supporting environmental history, political ecology and the research program of modernity/coloniality, it now becomes possible to approach a consideration of the coloniality of Latin American nature.

a) To begin, a suggestive observation is presented by Fernando Coronil from the perspective of the M/C Program. It refers to the anthropocentrism of narratives of the origins of modernity, parallel to eurocentrism, and highlights the fundamental role of nature in colonial spaces (basically, mineral resources or tropical lands) in the genesis of modernity. In highlighting the presence of this coloniality of tropical nature, Coronil displaces European self-sufficiency in producing modernity and capitalism, and locates "its birth and evolution not in Europe, to which the dominant historiography has restricted it, but in the already globalised interactions between Europe and its other colonies [...] Instead of seeding a self-generated European phenomenon that spread to the rest of the world, capitalist modernity appears as the result of its transcontinental transactions, whose truly global character only began with the conquest and colonisation of the Americas" (2000: 92-93).

The incorporation of American nature (in the sense of environment) into a condition of inferiority, as a resource to be exploited, accompanied the logic that Boaventura de Sousa Santos calls "imperial discoveries" (2006, chapter 4). Imperial discovery always supposes the production of mechanisms that interiorise and subordinate the discovered in order to colonise and exploit it, 
whether it is the Orient, the savages, or the tropical environment. In the case of the Americas, a "New World", these mechanisms were implanted and acted with much more efficiency and impunity than in Asia and Africa, ancient interlocutors of the European world.

It is important to highlight that in the American case, nature was undervalued to the point where the colonisers destroyed its valuable biodiversity to plant monocultures of exotic species for exportation. The northeast of Brazil and the Caribbean, the first areas to be colonised through this regime of production, had their original vegetation cleared for the production of sugar cane. That is to say, they were conceived merely as a platform of tropical lands incorporated into the European hegemonic space, appropriated for a production of great benefit. ${ }^{21}$ This is an example of what Polanyi referred to as the utopia of the transformation of Nature into land. This original event already defined the characteristics of the coloniality of nature in the Americas, which continues to repeat itself in the 21 stcentury, with the expansion of soy and agrofuel monocultures. ${ }^{22}$

b) Just how radical this process of colonising nature is can also be explained by how radical the process of colonising humans is, which until then Europeans had not had occasion to apply with such efficacy. It is sufficient to note that there have been studies that estimate that during the course of the first century of conquest, the original population of the Americas was reduced to $10 \%$ of that at the time of discovery. This sad record is not only limited to the direct, violent actions of the colonisers, but other natural factors played a role as well: epidemics of diseases

21 "Quickly discovering that the lands of the northeast lent themselves marvellously to the cultivation of sugar cane, the colonisers sacrificed all other possibilities in order to exclusively plant cane. For the interests of this untimely monoculture, nearly all life in the region, both animal and vegetable, was destroyed, completely subverting the ecological equilibrium of the landscape and blocking all other attempts at the cultivation of foodstuffs in the region. Thus, the food resources of the region were degraded in the extreme." (Josué de Castro, no date: 107).

${ }^{22}$ In the Argentinian province of Salta, between the 1988 and 2002 censuses, the area covered by soy increased by $50 \%$. In the same period, "the area with forests and natural mountains went from 3.7 million hectares to 2.2 million, a loss of 1.5 million. It is calculated that since 2002 , 800,000 more hectares have been cleared, of which half a million correspond to 2007 alone. [...] The average number of hectares per agricultural unit in Salta went from 93.7 in 1998 to 132.7 in 2002. Lands dedicated to soy in 2002 , meanwhile, averaged 590 hectares. Furthermore, in 2000 , 95,000 hectares were in the hands of 19 producers, and just one of them had 25,000" "Soya y bosques nativos" 2009: pg 12, Cash Supplement, Buenos Aires, 29 of March). 
that arrived with the invasion, for which indigenous populations did not possesses antibodies, and the disruption and/or destruction of native productive ecosystems.

c) Continuing the argument of the previous point, which associates monoculture/destruction of native/colonial ecosystems, one can prove that currently the greatest reserves of biodiversity left on the continent are located in indigenous territories, forming the so-called "biocultural diversity". We can recount the Mesoamerican example: "In Mexico, half of all public lands and indigenous communities (close to 15,000) are located in only those ten states considered to be the richest in biological terms." A team from CONABIO listed 155 areas as priorities for biological conservation in the territory of the republic, and 39\% of them overlaid indigenous territories. This proportion rose to $70 \%$ in the centre/south of the country. "Five of the six Biosphere Reserves located in Central America are found to be inhabited by different indigenous communities (Toledo et al, 2001: 23-24). ${ }^{23}$

d) The modernity/coloniality complex, in its epistemological implications, produces points of view that organised humans by the purity of their blood and denigrated the biodiversity of the tropics, perceived as not appropriate for civilised society. ${ }^{24}$ For one of the original theorists of the modernity/coloniality perspective, Aníbal Quijano, the social classification based on racial criteria appeared alongside the Iberian colonisation of the Americas, and ended up being the constituting category of world power:

Coloniality is one of the constitutive and specific elements of the global pattern of capitalist power. It is founded on the imposition of a raciallethnic classification of the world's population as a cornerstone of said pattern of power, and operates on each of the planes, areas and

\footnotetext{
23 This does not mean, of course, failure to record the possible environmental crises that could have occurred in Mesoamerica, thoroughly proven in the case of the Mayan cities (Gill, 2008).

${ }^{24} \mathrm{~A}$ long retelling of the European narratives and discourses about the inferiority of the American environment between the 18th century and 1900, always linked to the inferiority of its original populations, was developed in the classic book by Antonello Gerbi (1996). Probably the work of greatest complexity available on the appearance of this point of view in the American natural sciences was the erudite La Hybris del punto cero, by Santiago Castro Gómez (2005). Another important Colombian for this discussion is Remedios para el Imperio, by Mauricio Nieto Olarte (2006).
} 
dimensions, both material and subjective, of daily existence and the social ladder (Quijano, 2007: 93).

But it is clear that the genocide and subordination of the original population meant the loss of their knowledge and traditional ways of interacting with nature. At the same time, there was a selective reorganisation of knowledges, stemming from new power relations. There was an appropriation of American plant species and the technologies associated with them, which saved Europe from the threat of starvation. There was a rearrangement of cognitive structures, of what could and could not be known, and even planted. ${ }^{25}$ It was crucial that the Spanish maintained indigenous knowledge that referred to the management of nature and its necessary uses in order to provide sustenance and, if possible, production for the market. ${ }^{26}$ In the Brazilian case, Sergio Buarque de Hollanda (1977) studied the incorporation of different indigenous technologies by expeditionaries confined to an unknown territory.

e) Jean Brunhes (1869-1930) was a notable French geographer, known amongst other things for directing, from 1909, a massive project of visual documentation of the planet (Archives de la planète), which produced 72,000 photos and 183,000 meters of photographic film across 50 countries. His work inspired the historiographic perspective of Marc Bloch and of the school of the Annales. But it is also a precursor to the ecological critique of colonial devastation.

In 1910, in his book La Géographie Humaine, he refers to a peculiar modality of "destructive occupation" of space by the human species, "which tend to first strip mineral, vegetable, and animal materials without any idea or method of restitution". In extreme cases, adds Brunhes, the destructive occupation presents "an unmoderated intensity, that merits the terms 'economic pillage' or, more

${ }^{25}$ It is interesting to verify that the culture of the conquest also established interdictions over American plants. Such was the case of amaranth (huaut/i), which served as material for small idols in Mesoamerican religious rituals. "These idols were broken into small pieces, shared between those present, and thus consumed. This type of ceremony appeared similar to the Christian Eucharist in the eyes of the conquistadores, for which both its cultivation and consumption were prohibited" (Hernández Bermejo and León, 1992: 91). An excellent example of the relation between biology and history, mediated by power and culture that Arturo Escobar could use!

26 Equivalent practices are now reproduced in relation to indigenous knowledges around biodiversity, pharmacology, vegetable cosmetics, etc. 
simply, if you prefer, 'devastation'. Devastation accompanies civilisation, while savages only know it in attenuated forms." Its victims are not only the elements of nature, but also indigenous peoples.

Among the principle processes of destructive occupation indicated by Brunhes are two that are fundamental for Latin America. The first is mineral exploitation, which "under the name of devastating exploitation, includes the abusive exploitation that, for want of immediate benefits, becomes over-extended", and he cites the case of guano deposits in Peru The other is that of monocultures, that attack the soil "avidly robbing it of its fundamental nutrients, wanting to produce with minimal costs and without compensation. In Western Europe, with its dense population and its extremely intensive cultivation, there is hardly devastation; necessity has taught the use of fertilisers. The same did not occur in colonised countries" (Brunhes, cited in Castro Herrera, 1996: 35-37).

f) Halfway between the two epochs, the important, pioneering book of Enrique Leff, Ecologia y Capital, presented a complete formulation of the coloniality of Latin American nature and its effects, although still being a part of the discussion on "under-development". For Leff, the situation of colonial or neo-colonial dependence and unequal exchange provoked:

$[\ldots]$ the destruction of the resource system and the degradation of the productive potential of the ecosystems that constituted the foundations of the sustainability of these countries' productive social forces [...] Its most enduring effect was produced by the destruction of the productive potential of Third World countries, by the introduction of inappropriate technological patterns, by the induction of extractive rhythms, and by the spread of social models of consumption that generated a process of ecosystem degradation, soil erosion, and resource depletion [...] Underdevelopment is the effect of the loss of the productive potential of a nation, due to a process of exploitation and spoilage that destroys the ecological and cultural mechanisms upon which depend the sustainable production of productive forces and regeneration of natural resources [...] One of the most important transformations consisted in eliminating traditional agricultural practices, founded in the diversity of cultivars and adapted to the ecological structures of the tropics, in order to induce monocultural practices intended to satisfy the demands of the external market (Leff, 1986: 155-159).

Here, clearly demonstrated by Enrique Leff, is the principal mechanism of accumulation and reproduction of the coloniality of Latin American nature, in 
terms that could perfectly resemble those of Brunhes or the contemporary perspective of Mike Davis, a devastation that destroys or disorganises ecosystems and autochthonous productive systems and negate the autonomous potentials of these societies.

Another author that furthered the quandary of the coloniality of nature's persistence in our region was Guillermo Castro Herrera, in a book dedicated to outlining a possible Latin American environmental history.

It could be said that over the course of the last five-hundred years, the environmental history of Latin America has been marked by two great characteristics, which developed from the 16th century. The first, of an economic nature despite enormous demographic, social, political and cultural implications, refers to the redistribution and revaluation of the natural resources of the region in function of the demands generated by successive metropolises, which explains the specialised and discontinuous, though always predatory, nature of the exploitation of the same. The second, of a technological nature, is related to the incapacity of the region to establish for itself the financing, means, methods, sources of energy, procedures for waste disposal, and, above all, the associated propositions for this natural resource exploitation (Castro Herrera, 1996: 6566).

g) From a point of view that attempts to reunite the M/C Program with the contributions of environmental history and political ecology, we argue that contemporary globalisation carries at its core the aspiration of imposing a singular model of modernity. Paradoxically, globalisation also comes to highlight questions of difference, in the form of emerging cultural, ethnic, and particularistic conflicts, which can be schematically referred to as "politics of difference". They cannot be classified as "anti-modern", and it seems more interesting to reflect on them from the criterion of "trans-modernity", an anthropographic acceptance of the potentially liberating elements contained in the unfinished project of modernity, "which does not have modern solutions for the conflicts and crises it provokes", in the words of Boaventura de Sousa Santos.

The modernist project always implies the use of biopower over nature, understood as power over physical-geographical spaces—soils and subsoils, natural resources, flora and fauna-taking advantage of climactic conditions, but also power over subaltern 
human bodies through domination. Biopolitics of modern/colonial discourses do not only produce subjectivities and territorialities, they also produce "natures". That is to say, they reveal the colonialities of "natures".

It deals with the hegemonic validity of a perspective of "observation" that was characterised in the works of Michel Foucault. Observation, secularised and pragmatised for the ends of territorial control ("governmentality") and the production of marketable goods, supposes the construction of a timeless, impersonal and universalising point of view, a true "point zero". This is the point form which modern scientific discourse and the social practices founded upon it make their pronouncements (Castro Gómez, 2005).

The emergence of conflicts provoked by globalisation deconstructs this perspective and struggles to legitimate other points of view, incorporating a true "heterarchy" of conflicts (Castro Gómez; Grosfoguel, 2007). It is not just an environmental crisis, but one of fragmentary issues, localised and timely but, at the same time, generalised and conclusive, which pierces definitions of the environmental as a specific arena of conflict and discourse, and which encompasses, as an entirety, the whole modernist project (or the current development model).

Returning to the definition proposed by Arturo Escobar of political ecology as the study of different articulations between biology and history, let us now say that for this author " $[. .$.$] each articulation has its history and specifications, and it is related$ to modes of perception and experience, determined by social, political, economic and knowledge-based relations and characterised by modes of spatial use, ecological conditions, and more. The work of political ecology is to delimit and characterise these processes of articulation", to those he calls "regimes of nature" (Escobar, 2005a: 25).

In Latin America, since the Iberian conquest, a diversity of regimes of nature have coexisted, with the hegemonic and colonising predominance of those oriented toward securing governmentality and the production of exchange value. In varying degrees of subordination or relative isolation, other regimes of nature have constituted 
strategies of survival or resistance, such as small-holding, indigenous groups, palenques, etc. Just as this coexistence has endured over time, the overwhelming impetus for destructive occupation is renewed over regions that had remained relatively marginal in this dynamic, such is the case of the Amazon.

In a work prepared for the Fourth Brazilian Congress of Agroecology, realised in Porto Alegre from the 18th to 21st of November 2004, we worked with the notion of the hybrid character of Latin American cultures (García Canclini, 2003), applied to the sphere of landscapes, natures, and, more specifically, agricultural knowledges, in an attempt to include in this dimension a viable approach to a possible Latin American heritage and identity (Alimonda, 2004). The imperial projects of modernity were never entirely completed. They couldn't be, because they don't know their limits, because they are based in a colonialism that provokes destruction in its wake, which ends up rendering the modernist project unfeasible, and, furthermore, because it has always faced resistance. As a result, Latin American cultures and natures, through different heritages, have been constituted as hybrid entities. It is the current task to recover the plural character of this heritage, letting it "hybridise" in response to emergencies that are often contradictory and utopic. In this way, a path of reconciliation will be laid out, not only political, social and environmental, but also epistemological, between society and nature, between knowledge and respect for an "economy of nature" and the ethical imperatives of social organisation, in the form of a "moral economy" (to use 18th century terms). In this moment, in which the crisis of the dominant models appears unquestionable, it becomes ever more important to advance the construction of alternatives. Mobilising all our identities and putting in action all our heritages and capacities, in whichever place within Latin America.

\section{References}

Alimonda, Héctor (comp.) 2006 Los Tormentos de la Materia. Aportes para una Ecología Politica Latinoamericana (Buenos Aires: CLACSO). 
Alimonda, Héctor 2004 "Una herencia en Manaos: Anotaciones sobre historia ambiental, ecología política y agroecología en una perspectiva latinoamericana” in Canuto, João Carlos y Costabeber, José Antonio (eds.) Agroecología - Conquistando a soberania alimentar (Pelotas: Emater).

Alimonda, Héctor (coord.) 2002a Ecología Politica. Naturaleza, sociedad y utopia (Buenos Aires: CLACSO).

Alimonda, Héctor 2002b "Nos sertões de Tomochic, a guerra infinita" in Revista Brasileira de Sociologia da Emoção (João Pessoa), Vol. 1, No. 3.

Alvarez, Sônia et al. 2000 "Introduction: The Cultural and the Political in Latin American Social Movements" in Alvarez, Sônia et al. Culture of Politics, Politics of Culture: Revisioning

Latin American Social Movements, (Boulder: Westview Press).

Bebbington, Anthony 2007 "Elementos para una ecología política de los movimientos sociales y el desarrollo territorial en zonas mineras" in Bebbington, Anthony Mineria, movimientos sociales y respuestas campesinas. Una ecología politica de transformaciones territoriales (Lima: IEP/CEPES).

Bryant, Raymond y Bailey, Sinéad 1997 Third World Political Ecology (London: Routledge).

Buarque De Holanda, Sérgio 1977 Visão do Paraíso (San Pablo, Editora Nacional. Castro Gómez, Santiago 2007 La Hybris del Punto Cero. Ciencia, raza e ilustración en la Nueva Granada (1750-1816) (Bogotá: Universidad Javeriana).

Castro Gómez, Santiago y Grosfoguel, Ramón (eds.) 2007 El giro decolonial. Reflexiones para una diversidad epistémica más allá del capitalismo global (Bogotá, Universidad Javeriana/ Universidad Central/Siglo del Hombre).

Castro Herrera, Guillermo 1996 Naturaleza y sociedad en la historia de América Latina (Panamá: CELA).

Coronil, Fernando 2000 "Naturaleza del poscolonialismo: del eurocentrismo al globocentrismo" en Lander, Edgardo (eds.) La colonialidad del saber: eurocentrismo y ciencias sociales (Buenos Aires: CLACSO). 
Cronon, William 2002 "Un lugar para relatos: naturaleza, historia y narrativa” en Palacio, Germán y Ulloa, Astrid (eds.) Repensando la naturaleza. Encuentros y desencuentros disciplinarios en torno a lo ambiental (Bogotá: Universidad Nacional de Colombia/ICANH).

Crosby, Alfred 1993 Imperialismo ecológico (San Pablo: Companhia das Letras).

Chatterjee, Partha 1998 "Five Hundred Years of Fear and Love" in Economic and Political Weekly, Vol. 33, No. 22, pp. 1330-1336.

Chatterjee, Partha 2008 La nación en tiempo heterogéneo (Buenos Aires: Siglo XXI/CLACSO).

De Castro, Josué s/f Geografia da fome (San Pablo: Círculo do Livro).

De Sousa Santos, Boaventura 2006 Conocer desde el Sur (Lima: UNMSM), Cap. IV.

Domínguez, Diego y Sabatino, Pablo 2006 "Con la soja al cuello: crónica de un país hambriento productor de divisas" en Alimonda, Héctor (eds.) Los tormentos de la materia. Aportes

para una ecología politica latinoamericana (Buenos Aires: CLACSO).

Dussel, Enrique 2000 "Europe, Modernity and Eurocentrism” in Nepantla, Vol. 1, N³.

Enzenberger, Hans M. 1974 Para una crítica de la ecología política (Barcelona: Anagrama).

Escobar, Arturo 2005a "Depois da Natureza - Passos para uma Ecologia Política antiessencialista” en Parreira, Clélia y Alimonda, Héctor (orgs.) Politicas Públicas Ambientáis Latinoamericanas (Brasilia: Abaré/FLACSO).

Escobar, Arturo 2005b "Mundos y conocimientos de otro modo: el Programa de Investigación de Modernidad/Colonialidad" en Escobar, Arturo Más allá del Tercer Mundo: Globalización y Diferencia (Bogotá:ICANH).

Escobar, Arturo 1996 La invención del Tercer Mundo. Construcción y deconstrucción del desarrollo (Bogotá: Norma).

García Canclini, Nestor 2003 Culturas hibridas (México: Grijalbo). 
Gerbi, Antonello 1996 O Novo Mundo - História de uma polémica (1750/1900) (San Pablo: Companhia das Letras).

Gill, Richardson B. 2008 Las grandes sequias Mayas: agua, vida y muerte (México: FCE).

Hardt, Michael y Negri, Antonio 2000 Empire (Cambridge: Harvard University Press).

Harvey, David 2004 “El 'nuevo' imperialismo: acumulación por desposesión” en Panitch, Leo y Latour, Bruno Politicas da Natureza (Bauru: EDUSC).

Latour, Bruno 2007 Nunca fuimos modernos. Ensayo de antropología simétrica (Buenos Aires, Siglo XXI).

Leff, Enrique 2006 "La ecología política en América Latina: un campo en construcción” en Alimonda, Héctor (comp.) Los Tormentos de la Materia. Aportes para una Ecología Política latinoamericana (Buenos Aires: CLACSO).

Leff, Enrique 1986 Ecología y Capital (México: Siglo XXI).

Lévi-Strauss, Claude 1976a Antropologia Estrutural II (Río de Janeiro: Tempo Brasileiro), Cap. XVII.

Lévi-Strauss, Claude, 1976b Structural Anthropology, vol. 2 (New York: Basic Books).

Leys, Colin 2005 (comp.) “El nuevo desafío imperial” Socialist Registrer 2004 (Buenos Aires: CLACSO).

Lipietz, Alain 2003 "A ecologia política e a crise do marxismo" in Ambiente e Sociedade (Campinas), Vols. 1-2.

Lipietz, Alain 2002 “A ecologia política, solução para a crise da instância política?” in Alimonda, Héctor (comp.) Ecología Política. Naturaleza, sociedad y utopia (Buenos Aires: CLACSO).

Lipietz, Alain 1999 Qu'est-ce que l'écologie politique? La Grande transformation du XXI siècle (París : La Découverte).

Luxemburg, Rosa 2015 The Accumulation of Capital (London: Routledge). 
Luxemburgo, Rosa 1967 La acumulación de capital (México: Grijalbo).

Machado Aráoz, Horacio s/f "De la 'Naturaleza' como objeto colonial a la condición ecobiopolítica del colonialismo contemporáneo”, mimeo.

Martínez Alier, Joan 2004 El ecologismo de los pobres. Conflictos ambientales y lenguajes de valoración (Barcelona: Icaria/ FLACSO).

Melville, Elinor 1999 Plaga de ovejas. Consecuencias ambientales de la conquista de México (México: FCE).

"Metabolismos rurales: hacia una teoría económico-ecológica de la apropiación de la naturaleza" Revista Iberoamericana de Economía Ecológica, Vol. 7, 2008.

Mignolo, Walter 2007 "El pensamiento decolonial: despredimiento y apertura. Un manifiesto" en Castro Gómez, Santiago y Grosfoguel, Ramón (eds.) El giro decolonial: reflexiones para una diversidad epistémica más allá del capitalismo global (Bogotá: Universidad Javeriana/Universidad Central/Siglo del Hombre).

Mouffe, Chantal 2000 En torno a lo político (México: FCE).

Nieto Olarte, Mauricio 2006 Remedios para el Imperio. Historia natural y la apropiación del Nuevo Mundo (Bogotá: Uniandes-Ceso).

O’Connor, James 1998 Natural Causes: Essays in Ecological Marxism (New York: Guildford Press).

O’Connor, James 2001 Causas Naturales. Ensayos de marxismo ecológico (México: Siglo XXI).

Palacio, Germán s/f “5 ejes analíticos para comprender la Amazonia actual”, mimeo.

Palacio, Germán 2006 "Breve guía de introducción a la Ecología Política (Ecopol): Orígenes, inspiradores, aportes y temas de actualidad” in Gestión y Ambiente, Vol. 9, №3.

Palacio, Germán 2002 "Historia tropical: a reconsiderar las nociones de espacio, tiempo y ciencia” in Palacio, Germán y Ulloa, Astrid (eds.) Repensando la naturaleza. Encuentros y desencuentros disciplinarios en torno a lo ambiental (Bogotá: Universidad Nacional de Colombia/ICANH). 
Peet, Richard y Watts, Michael 2004 Liberation Ecologies. Environment, development, social movements (London: Routledge).

Pengue, Walter (comp.) 2008 La apropiación y el saqueo de la naturaleza. Conflictos ecológicos distributivos en la Argentina del Bicentenario (Buenos Aires: Fundación H. Boll/GEPAMA/Lugar Editorial).

PNUMA 2002 Perspectivas del Medio Ambiente Mundial (GEO-3) (Madrid: Mundi-Prensa).

Polanyi, Karl 2001 Great Transformation: The Political and Economic Origins of Our Time (Boston: Beacon Press).

Polanyi, Karl s/f The great transformation (Boston: Beacon Press).

Pyne, Stephen Fire in America. A Cultural History of Wildland and Rural Fire (Seattle: University of Washington Press).

Quijano, Aníbal 2007 "Colonialidad del poder y clasificación social" in Castro Gómez, Santiago y Grosfoguel, Ramón (eds.) El giro decolonial: reflexiones para una diversidad epistémica más allá del capitalismo global (Bogotá: Universidad Javeriana/Universidad Central/Siglo del Hombre).

Rodríguez, Javier 2009 Consecuencias económicas de la soja transgénica: Argentina 1996/2006 (Buenos Aires: CENDA).

Serje, Margarita 2005 El revés de la Nación. Territorios salvajes, fronteras y tierras de nadie (Bogotá: Uniandes/Ceso).

Toledo, Víctor et al. 2001 "El Atlas Etnoecológico de México y Centroamérica: fundamentos, métodos y resultados" in Etnoecológica (Morelia), Vol. VI, $N^{\circ}$ 8, diciembre.

Whitehead, Mark et al. 2006 "Spatializing the Ecological Leviathan: Territorial Strategies and the production of regional natures" in Geografiska Annaler, Vol. 88b.

Worster, David 1990 "Transformation of the Earth: Toward an Agroecological Perspective of History" The Journal of American History Mar, Vol. 76, No. 4. pp. 1087-1106.

Worster, Donald 2003 "Transformaçōes da terra: para uma perspectiva agroecológica na história" in Ambiente e Sociedade (Campinas), Vols. 1-2. 